\title{
Cultural Nationalism and Democracy's Opinion Leaders
}

\begin{abstract}
Probably not one man in a thousand is geared with sufficient heart action to run counter to a false public opinion. [...] There are just two such men in our hundred and odd millions today.

DOUGLAS FAIRBANKS, WRITING ABOUT T. ROOSEVELT AND W. WILSON, $1918^{1}$

Any description in words, or even any inert picture, requires an effort of memory before a picture exists in the mind. On the screen the whole process of observing, describing, reporting, and then imagining, has been accomplished for you.

WALTER LIPPMANN, PUBLIC OPINION, $1922^{2}$
\end{abstract}

\section{NATIONAL DEMOCRACY}

The war taught many lessons to American politicians and intellectuals. Past progressive understandings of what nationalism entailed gave way to more aggressive ones in the thick of novel practices of public opinion management. When in 1910 Roosevelt unveiled the program that came to be known as the "new nationalism," his politics of countering the era's profit-driven individualism and mobilizing a national sentiment for novel forms of welfare amounted to an inspiring platform for constructive, progressive change. ${ }^{3}$ The program also shared a surprising ideological convergence with The Promise of American Life, a volume that progressive intellectual Herbert Croly had written in 1909, four years before cofounding the New Republic. To today's readers, the word nationalism conveys ideological fanaticism and military belligerency. In Croly's analysis, nationalism was as a powerful unifier for a stronger democratic America. "It may discover," he argued, "that the attempt to unite the Hamiltonian principle of national political responsibility and efficiency with a frank democratic purpose will give [. . .] a new power to democracy." ${ }^{4}$ Together with the New Republic's other two cofounders, Walter Weyl and Walter Lippmann, Croly was rather blind to nationalism's domestic and, especially, international implications. Leading up to the war, ideas about America's power in the world, largely associated with Roosevelt's nationalist democracy, appeared 
to many progressive intellectuals to be legitimate and benign, notwithstanding an implicit advocacy for imperialist expansion. A prideful rhetoric of national democracy pervaded New Republic editorials and Wilson's speeches. But it also informed the publicists' and the president's efforts to shape public opinion about America's place in the world and about the war's meaning for America. Over time, the New Republic intellectuals came to disapprove of the unilateralist and imperialist policies first promoted by Roosevelt and then enacted by Wilson. Instead, they came to advocate a more restrained exercise of power politics. For his part, Wilson's actions showed publicists and readers alike how to discriminate "between those who would make power and those who would make democratic persuasion the ruling force in world politics." It was a move away from Rooseveltian power politics toward a strategy that viewed "world opinion" as the most effective "guarantee of peace."

The CPI's management of public opinion led many intellectuals to recognize disturbing occurrences of jingoistic manipulation and near-autocracy in the modern democratic experience. Until the sinking of the Lusitania, they hardly regarded nationalism as a conceptual rival to internationalism, but when they joined the country's war chorus, they realized that nationalism could acquire aggressive military connotations and sharp xenophobic edges. Randolph Bourne, a New Republic contributor and one of the most lucid voices in American intellectual life, saw the difference between the cultural nationalism he advocated and the destructive political nationalism prevalent in Europe and spreading across the Atlantic. In a June 1917 issue of the Seven Arts, he reproved his New Republic colleagues' "leadership for war" and their alignment "with the least democratic forces of American life." In his view, the government's systematic and effective management of public opinion, aided by illiberal forces, urged a pressing examination of world liberalism and world democracy. His article also called for a long-overdue investigation about the meaning of nationalism and democracy in America.? Bourne died prematurely in 1918, but his calls did not go unanswered.

In this chapter I discuss some of the period's critical contributions about political power and mass-mediated persuasion particularly, but not exclusively, among the influential editors of the New Republic. I examine the positions of Walter Lippmann and John Dewey on the delicate balance between democratic life and public opinion management, and I also discuss pervasive and glaring blind spots about alternative, transnational appreciations of America's exceptionalism. Cinema was not extraneous to these debates. Motion pictures became, especially in Lippmann's work, a paradigmatic form of powerful and manipulative knowledge: he referred to crowds' lingering prejudices as "pictures in their head" to bemoan the irrational process of mass communication and reception. The war decade saw more than the intervention of dystopian intellectuals, however. Enthusiastic publicity supporters were seeking ways to grant 
civic and commercial validation to public opinion management. History proved them right.

\section{UNIVERSALISM AND PLURALISM}

We are provincials no longer.

WOODROW WILSON, SECOND INAUGURAL ADDRESS, MARCH $1917^{8}$

On paper, Wilson's eloquent rhetoric was not especially straightforward, but his message was compelling and became even more so during wartime. Key to his communicative success was the mediating role of personal emissaries and CPI activists. With great efficacy, they projected his charismatic presence and oratory into the exclusive circles of America's intellectual and business elites and the more expansive national press. They translated and broadcast Wilson's widely repeated phrase that Americans entered World War I "for no selfish advantage" and that the U.S. troops were "the armies of God" sent on a mission to redeem the continent." Wilson's own communication armies divulged his high-minded millenarian and transcendent rhetoric about America as a paragon of democracy for mankind. ${ }^{10}$ Ultimately, his Fourteen Points appeared as a covenant of peace, drafted to grant justice to weak nations and stateless minorities through the recognition of all peoples' legitimate interests under universal justice.

At war's end, America and the Allied powers continued to view the conflict through Wilson's eyes: as the Old World's "final emancipation" from "autocratic authority" and as America's way "to redeem [it] by giving it liberty and justice." Wilson's civic religion led to morally inflected international policies that achieved very practical results. As Daniela Rossini put it, "Wilson led the United States in the transition from its provincialism and isolationism toward international engagement and world political leadership." ${ }^{12}$ Not only was he the first "statesman to propose a supranational political organization, the League of Nations," but he was also "the first American president to urge his compatriots to become citizens of the world." ${ }^{13}$ No other president had ever achieved such intense ideological mass mobilization in America or the world. It should not be surprising that when comparing Roosevelt with Wilson, Croly thought of the former as a "hero" and the latter as a "saint," which contributed to a sacralized political legitimation of the modern statesman. ${ }^{14}$ Only in retrospect did Croly, Lippmann, and even Dewey see how their "cant of idealism" had blinded them to Wilson's "autocratic and coercive methods," which had led to the creation of an artificial national enthusiasm and unity. ${ }^{15}$

By turning the war into a crusade for democracy, Wilson's political millenarianism represented a universalistic, apparently all-inclusive aspiration. In truth, it was not. On the one hand, it was fraught with divisiveness as it presented a remarkable undercurrent of social Darwinism. Wilson's Anglo-Saxonism informed his notion of American exceptionalism, which compromised not only his internationalist 
democratic program but also his view of national differences in America. Even though he twice opposed immigration restriction bills that called for a literacy test, he abhorred "hyphenated" immigrants because, in Hans Vought's words, "they acted as groups, and put selfish group interests blindly above the national interest." ${ }^{16}$ On the other hand, Wilson's millenarianism informed a distinct notion of American exceptionalism, which hindered his internationalist program because it sanctioned, paternalistically, the call for collective security to "restrain national egoism." ${ }^{17}$

The peace conference and its aftermath shattered these aspirations and provoked disturbing realizations. Wilson wanted a people's peace, and instead what he and his American supporters were forced to accept was a punitive one. Versailles put into question the meaning and promise of Wilsonian Americanism and defeated the idealism of Wilson's brainchild, the League of Nations. The Republican Senate did the same by blocking U.S. entry into the league in 1920, as many former supporters turned against the president. The New Republic rejected the Versailles Treaty, claiming it "merely [wrote] the future specifications for revolution and war." ${ }^{18}$ Wilson's suppression of all dissent during the war years and his postwar betrayal of his idealist and internationalist principles shattered the remnants of American progressivism, marginalized new liberalism until the Depression reintroduced some of its principles, and disillusioned the new liberals' longing for a great reformist leader, "something of a saint and something of a hero." ${ }^{19}$

Over time, historians and commentators have posited that Wilson himself contributed to the defeat of his own idealistic policies. As Lippmann observed in 1919, Wilson's decision not to promote the League of Nations prior to the end of the war led to his failure to design a world community. But his racially isolationist ideology may have also contributed to the failure of his global politics. Under his presidency, the CPI sought to address the country's various national constituencies by targeting the ethnic press with news, bulletins, and various propaganda communications, all published in translation. But Wilson, like Roosevelt before him, dealt with immigrants either as outsiders or as subjects to be Americanized and, as such, as a domestic problem seemingly divorced from foreign policy. ${ }^{20}$ While domestic pluralism was not an easy option for the president, in the mid-1910s progressive intellectuals had elaborated alternative views that would find fertile ground in 1920 s film culture. Two in particular deserve mention.

In his influential essay "Democracy versus the Melting-Pot," published in the Nation in 1915, the Jewish American philosopher and academic Horace M. Kallen identified in "the practical fact of ethnic dissimilarity among the whites of the country" a subject unknown to authors of the Constitution. ${ }^{21}$ Writing against the primacy of the pure "English American," Kallen explicitly critiqued the nativist positions embraced by the prominent sociologist E. A. Ross and President Wilson, 
among others. He judged their "resentment of the 'hyphenated' American" as "righteous and pathetic" 22 and sought to disengage Americanism from Anglo-Saxonism. Once in America, he argued, immigrants had found economic prosperity, but they also turned their ethnic and national differences "from disadvantage to distinctions." ${ }^{23}$ This was possible, he continued, because "on the whole, Americanization has not repressed nationality. Americanization has liberated nationality." ${ }^{24}$ He thus compared American society to a symphonic orchestra in which "each ethnic group is the natural instrument, its spirit and culture are its theme and melody, and the harmony and dissonances and discords of them all make the symphony of civilization." ${ }^{25}$

This conclusion both anticipated and influenced the work of the aforementioned Randolph Bourne, whose famous essay "Trans-National America" appeared a year later in the Atlantic Monthly. "The failure of the melting-pot," Bourne argued, "far from closing the great American democratic experiment, means that it has only just begun." By admitting the necessity for "a clear and general readjustment of our attitude and our ideal," ${ }^{26}$ Bourne recognized that America's "unique sociological fabric" could open a path to a new kind of cosmopolitan unity and interchange and avoid the dangers of European nationalism. Calling for "a higher ideal than the "melting pot," "whose long predominance had inspired an Americanism conjugated mainly in the past tense, he concluded with this sentence:

America is coming to be, not a nationality but a trans-nationality, a weaving back and forth, with the other lands, of many threads of all sizes and colors. ${ }^{27}$

Rare among intellectuals of the time, Bourne understood that the notion of immigrants' isolation from their homelands matched Americans' widely held belief of their own nation as isolated. "To stigmatize the alien who works in America for a few years and returns to his own land," he wrote, "is to ignore the cosmopolitan significance of this migration." ${ }^{28}$ The war in his view made untenable the isolation from Europe as well as the tradition of remaining "aloof and irresponsible." ${ }^{29}$ On the constructive side, Bourne maintained that the work of the "younger intelligentsia of America" was to aim at a "higher cosmopolitan ideal[, . . .] a spiritual welding, which should make us, if the final menace ever came, not weaker, but infinitely strong." ${ }^{\circ}$

Even though the discursive emergence of a "trans-national" and cosmopolitan America did not overcome the competing racial discourses and anti-immigration policies, it nonetheless revealed the highbrow formulation of cultural pluralism-later expanded upon by John Dewey-that saw parallel reverberations in American popular culture..$^{31}$ Eventually, lowbrow versions of cultural pluralism emerged in the performative arts and sanctioned an attraction to foreign personalities and their elevation as testimonials for a new America. One question remains: in a cultural environment where large, powerful sections of American 
public opinion viewed transnational exchanges as miscegenational, how could any embrace of foreign performers' masculinity be possible and even desirable? A possible answer lies in reframing the question. Rather than considering foreignness as a problem, it may be helpful to regard the foreigner, to quote Bonnie Honig, "as a device that allows regimes to import from outside (and then, often, to export back to outside) some specific and much-needed but also potentially dangerous virtues, talent, perspective, practice, gift, or quality that they cannot provide for themselves." 32 As we shall in the remainder of this study, in the context of lively debates about public opinion management as both a growing cultural phenomenon and as a controversial political instrument, foreignness could be regarded as "a site at which certain anxieties of democratic self-rule are managed [...] as a way to frame other issues of democratic theory and citizenship." ${ }_{33}$

\section{POWER AND PERSUASION}

Before the end of the war, while some commentators praised Wilson's ability to avoid democratic inaction or, even worse, "mobocracy," others accused him of bypassing the authority of Congress and autocratically manipulating the will of the people. Implicitly attacking the president, a Chronicle editorial from 1918 called CPI director George Creel America's "publicity dictator." ${ }^{34}$ After the war, many progressives and former Wilson supporters expressed fears that wartime propaganda practices were not about to end. "Shaping public opinion has become an essential industry," wrote John Dewey in 1918. A year later Progressive journalist William "Will” Henry Irwin, who had directed the CPI's program of overseas propaganda, warned that special interests continued "to slant, to bias, to color the news," well after the armistice was signed..$^{35}$ From the left, Socialists attacked Creel's promotion of Wilson as enhancing a dangerous "HERO WORSHIP" that "leads a mad stampede away from an orderly movement toward concentration of power, in order to follow some Messiah." ${ }^{36}$ Toward the end of the 1910s, a few political cartoons in the New York Tribune depicted Wilson with a good dose of sarcasm. One of them captured the president as a farmer planting the seeds of the peace treaty, watered by his oratory, in the garden of public opinion, not far from the U.S. Senate (figure 5).

Because the press's exposure of party corruption required candidates to present themselves directly before their electors, politicians understood that their ability to influence the press was the only antidote against an out-of-control public opinion determining government policies. The challenge was to limit the "questions to which public opinion can apply," as Harvard president Abbott Lawrence Lowell had put it. ${ }^{37}$ In other words, since in principle most scholars equated democracy with popular sovereignty and understood democracy as "government by public opinion," the challenge was to distinguish proper public opinion from crowds' irrational beliefs without denying legitimate demonstrations of popular will..$^{8}$ 


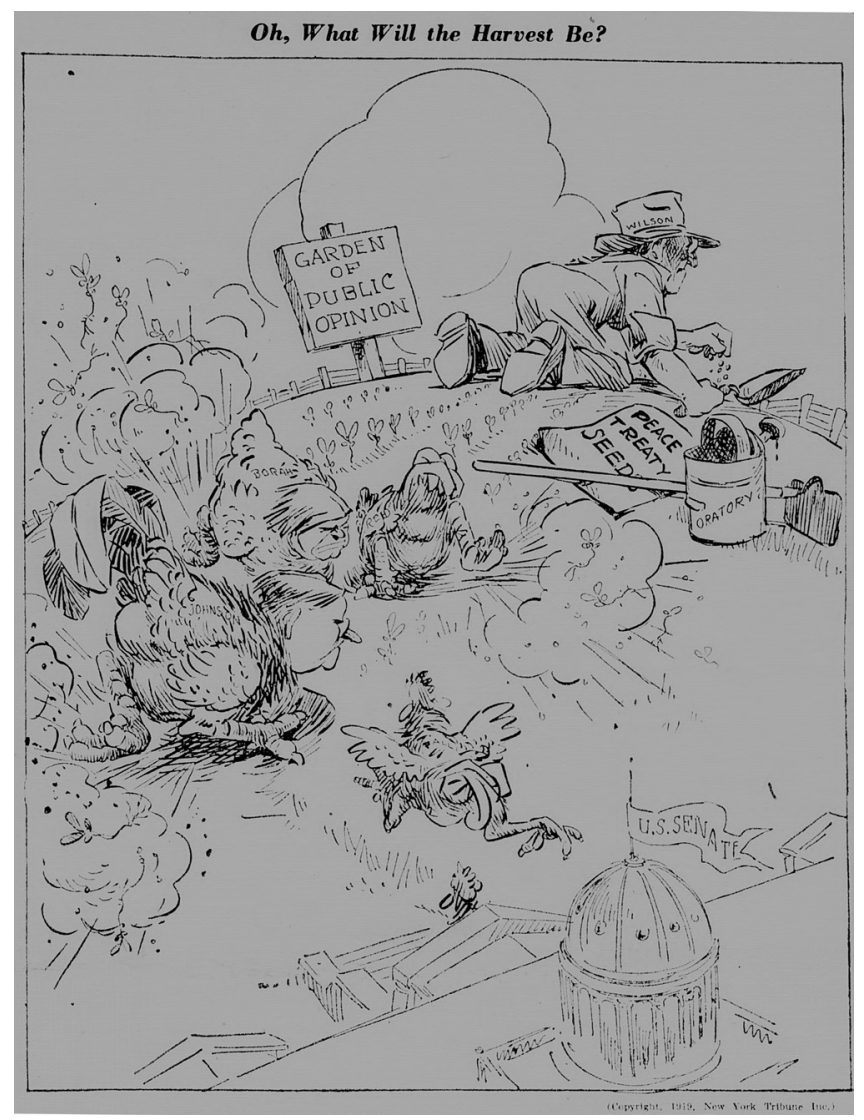

FIGURE 5. President Wilson planting the seeds of his peace treaty. New York Tribune, September 2, 1919, 1.

One of the volumes most explicitly stressing the dangers of "crowd-mind" and "crowd-behavior" was Everett D. Martin's The Behavior of Crowds. In contrast to the antidemocratic stance of Le Bon but mindful of Tocqueville's warning about the tyranny of democratic majorities, Martin argued that "democracy has indirectly permitted, rather than directly caused, an extension in the range of thought and behavior over which the crowd assumes dictatorship." ${ }^{39}$ His solution relied on the Deweyan empowerment of education, which he viewed as the prerogative of a select group of individuals, "men capable of philosophical tolerance, critical doubt and inquiry [...] who can rise above vulgar dilemmas and are deaf to crowd propaganda." ${ }^{\circ}$ It was an elitist view that several public figures openly supported, including most famously Walter Lippmann, oftentimes on the basis of their direct experience of mass-mediated war propaganda. 
At the center of these ideas was the concern that the massive expansion of the means and venues capable of informing public opinion challenged old formulations of popular sovereignty. Since the mid-1910s, as Progressivism was retreating from mainstream political discourse, Lippmann had begun to reflect on the relationship between public opinion and political action within democratic life. His war experience as columnist, assistant to the secretary of war, and general secretary of a secret intelligence unit, the War Data Investigation Bureau, informally known as the Inquiry, shaped his understanding of information's critical role for policy making.

Based at the New York Public Library on 42nd Street and made of historians and geographers, the Inquiry was entrusted with drawing Europe's postwar internal borders ahead of the peace conference. Between late 1917 and early 1918, Lippmann and his associates drafted a memorandum that "delineated the new European frontiers, explained how each decision was made, and illustrated the points with maps." Wilson "added six general principles of his own on the territorial points," and the Inquiry memorandum became the basis of the president's historical Fourteen Points speech to Congress on January $8 .^{41}$ After this initial success, the rest of Lippmann's war experience as propagandist and as a member of the American entourage in Paris was disheartening. ${ }^{42}$ His immediate superior, Edward M. "Colonel" House was demoted, and the press bureau was handed to Creel. Lippmann despised the CPI director's approach to propaganda as a means to win the war but not to secure long-lasting peace. Disappointed at how Wilson's concessions at Versailles had profoundly undermined the principles of the peoples' war, he returned to the States and in the New Republic excoriated the treaty as a "prelude to quarrels in a deeply divided and hideously embittered Europe." 43

In the following years, he published three dystopian volumes that reflected not only on the dangers of propaganda but also on the distorting effect of the press in contemporary democracy. Against the faith in the press as a necessary component of democratic governance, in Liberty and the News Lippmann denounced what he called the "plebiscite autocracy, or government by newspapers." The result of the current situation, he wrote, is that political decisions "tend to be made by the interaction, not of Congress and the executive, but of public opinion and the executive." 44 In this scenario, private interest groups shape, or even produce, mainstream public opinion and in so doing control the government's policy and actions. "This shift in the locus of sovereignty," he somberly concluded, "has placed a premium upon the manufacture of what is usually called consent." 45

Lippmann directed his warning at the "protection of the sources of [. . . opinion," which he hailed as "the basic problem of democracy. Everything else depends upon it." ${ }^{66}$ His rather elitist solution was the employment of "expert organized reporters," who were not just individuals but also "institutes of government research" and "private agencies" assessing the technical work of government branches. ${ }^{47}$ 
Postulating that "the real enemy is ignorance," Lippmann advocated a disinterested news service impervious to special interests. Without it, he foresaw a country's degeneration into a dictatorship of the Left or of the Right. He redefined the traditional notion of "liberty," rejecting its traditional meaning as "permission" and reformulating it instead as "a system of information increasingly independent of opinion." 48

Two years later, Lippmann's outlook grew darker. The issue was not just the quality of the press or the legitimacy of government intervention in the production of news but the precarious assumption that human beings receive and process opinions through their rational faculties. In Public Opinion, he articulated his anxieties about the possibility of governing an ever-expanding mass citizenry democratically. Democratic theory, he contended, rested on the "doctrine of the omnicompetent citizen." ${ }^{49}$ In truth, in his view, common citizens did not necessarily make intelligent judgments even when presented with objective information. His wartime experience had taught him that facts could be manipulated and distorted and that human reception was not solely governed by rational faculties but operated on the basis of stereotypes formulated to confirm previous judgments and guarantee self-respect. Knowledge is ultimately linked not to experience but to preconceptions, which he aptly labeled "pictures in our head." These mental representations affect our physical perceptions: "We do not first see and then define, we define first and then see." ${ }_{50}$ Humans' first impetus is not the search for the truth itself, particularly if such pursuit means abandoning the comfort of familiar stereotypes. Referring to the famous allegory of Plato's cave, Lippmann argued that newly unchained prisoners, after a lifetime of mistaking shadows for real entities, decline resolutely to turn their heads..$^{51}$

Lippmann's dystopian notion of mediated democracy was dependent on his growing recognition of the imperfect workings of human knowledge. Rather than the traditional binary model of individual subjects responding to the outside world, human knowledge resulted in his view from "the insertion between man and his environment of a pseudo-environment" to which "his behavior is a response." Thus, Lippmann argued, "the analyst of public opinion must begin, then, by recognizing the triangular relationship between the scene of action, the human picture of that scene, and the human response to that picture." The ensuing conclusion was politically troublesome: "what each man does is based not on direct and certain knowledge, but on pictures made by himself or given to him." ${ }_{52}$

As his lexicon and discussion reveals, Public Opinion was not a mere academic exercise, but its references to moving pictures showcased a connection to popular culture as a most effective model of human knowledge and a most pervasive one of mass experience. The expression "pictures in our head," in fact, while long associated with Lippmann's analysis, had appeared in comparable forms in trade and film periodicals. A Photoplay editorial from September 1918, "War and 
the Fifth Estate," had self-servingly praised cinema for providing Americans with the only true understanding of the war. "As they gained a first-hand knowledge of events from the physical pictures on the screens," the editorial read, "their mental pictures of the war broadened into a true perspective of its overwhelming importance." 53 Whether or not Lippmann read film magazines, he was quite sensitive to the power of films as sources of mental pictures. "The moving picture," he argued, "often emphasizes with great skill this double drama of interior motive and external behavior." 54 When viewed as part of the history of visual representation, nothing could be "comparable to the cinema" because "photographs have the kind of authority over imagination to-day, which the printed word had yesterday, and the spoken word before that. They seem utterly real." In a point that recalls the politicized feedback loop discussed earlier, he also noted that "the moving picture is steadily building up imagery which is then evoked by the words people read in their newspapers." ${ }_{55}$ To illustrate moving pictures' cultural and political import, Lippmann turned to the most glaring example of his time, Griffith's racist blockbuster.

Your hazy notion, let us say, of the Ku Klux Klan, thanks to Mr. Griffith, takes vivid shape when you see the Birth of a Nation. Historically it may be the wrong shape, morally it may be a pernicious shape, but it is a shape, and I doubt whether anyone who has seen the film and does not know more about the Ku Klux Klan than Mr. Griffith will ever hear the name again without seeing those white horsemen. ${ }^{56}$

Four decades before Daniel Boorstin's dystopian notion of "pseudo-events," Lippmann's identification of pseudo-environments rested on a denunciation of the fallibility of human knowledge and, with it, of democracy. In a modern world that is "hurried and multifarious," he argued, citizens can make no judgments about the world based on firsthand knowledge but have to rely on facts and prejudgments, or stereotypes, created by them or created for them. ${ }^{57}$ The author of $P u b$ lic Opinion thus recognized that the original dogma of democracy, that rational knowledge should inspire policy, is but an impossible dream. No trustworthy press could ultimately cure the structural defects of democracy: the average man is unable or unwilling to process the barrage of information in order to formulate a competent opinion about a subject. Rather than just press bureaus, always subject to possible stereotypes and agendas, what Lippmann advocated were "intelligence bureaus," transparent and accountable, whose modus operandi was largely technical. "Representative government," he argued, "cannot be worked successfully, no matter what the basis of election, unless there is an independent, expert organization for making the unseen facts intelligible to those who have to make the decisions." ${ }^{8}$ Disillusioned with mass democracy and the press, Lippmann envisioned an insurmountable gap between well-informed insiders, who ultimately run the country, and distracted outsiders who think their opinion matters. In one of Public Opinion's last chapters, Lippmann struck a final blow to democratic theory when he contended that "the common interest very largely eludes public 
opinion entirely, and can be managed only by a specialized class." ${ }^{59}$ John Dewey famously described Public Opinion as "perhaps the most effective indictment of democracy as currently conceived ever penned." 60

In 1925, Lippmann painted an even darker view of democracy, if that was possible. In The Phantom Public he sought to "bring the theory of democracy onto somewhat truer alignment with the nature of public opinion." ${ }^{61}$ After positing that public opinion is "not the voice of God, nor the voice of society," he identified it as simply the voice of spectating common citizens, who have neither the time nor the preparation to attend to their government's affairs. They have to place their trust in the hands of actors, whose opinions and goals are not an "emanation of some common purpose." ${ }^{2}$ Liberalism, he admits with a mea culpa, had been contributing to this mistaken judgment.

For when public opinion attempts to govern directly it is either a failure or a tyranny [...] The theory of democracy has not recognized this truth because it has identified the functioning of government with the will of the people. This is fiction. ${ }^{63}$

By positing a "radical difference between the experience of the insider and [that of] the outsider," Lippmann was endorsing a conception of elitist democracy. ${ }^{64}$ He knew he was not alone. In The Phantom Public he referred to works that also regarded popular sovereignty as a fiction and that endorsed an elitist approach of modern democracy. ${ }^{65}$ He expressed particular sympathy for the German sociologist Robert Michels, whose Political Parties, published in the United States in 1915, popularized the concept of the inevitability, or iron law, of oligarchy in democratic societies. In later years, together with Alfredo Pareto and Gaetano Mosca, Michels became known as one of the key exponents of elitist theory and a supporter of the political experiment of Italian Fascism. ${ }^{66}$

Against Lippmann's elitist conception of politics, the philosopher, psychologist, and educational reformer John Dewey strove to defend the pragmatist wisdom of participative democracy. A widely known public intellectual versed in many disciplines and a public voice in matters of psychology, education, and aesthetics, Dewey had always expressed a profound belief in the values and practices of democracy. Pressed by Lippmann's writings on the unfeasibility of any democratic project, Dewey responded with the 1927 volume The Public and Its Problems. In it, he vehemently advocated for citizens' active role in shaping social issues and affecting decision-makers through communication and education. "Only through constant watchfulness and criticism of public officials by citizens," he maintained, "can a state be maintained in integrity and usefulness." ${ }^{67}$ Propaganda may not be eliminated, but a possible alliance of sound pedagogy and psychology with the scientific method could guide citizens, students, and workers along the path of correct reasoning. With the aid of communal life and "communicated experience," Dewey argued, "the cure for the ailments of democracy is more democracy." ${ }^{68}$ In contrast to Lippmann, he viewed modern media not as the 
arena where questions of public interest could potentially be accurately framed and structured but as a domain that generally distracts citizens from such questions. "The movie, radio, cheap reading matter and motor car," he argued, "did not originate in deliberate desire to divert attention from political interests," but that "does not lessen their effectiveness in that direction." He then concluded that "it is hard work to sustain conversation on a political theme; and once initiated, it is quickly dismissed with a yawn."69

To sum up, after the war experience, a renewed interest in public opinion became a major subject for editorialists as well as social and political scientists, no matter their ideological stance. At the start of the 1920s, attention to public opinion shifted from political and institutional concerns to the broad spectrum of social life, often touching upon the effects of manufactured consensus on political institutions. The co-optation of the disciplines of social psychology and, later, sociology led to public opinion being considered not strictly as political opinion but more as set of popular beliefs, including their formation, logic, and impact.

This interdisciplinary recasting affected the discipline of political science. The range of interests of Charles E. Merriam, founder of the behavioral approach to political science and a notable professor at the University of Chicago, was paradigmatic..$^{70}$ A pragmatic supporter of educating the citizenry, local participation, and representative democracy, Merriam had been the CPI's director of propaganda in Italy in 1918. A vehement supporter of scientific rigor, he promoted the study of political phenomena in the early 1920 s through the intersection of a wide range of research methods..$^{71}$ Merriam saw the still rising and imperfect discipline of social psychology, more than individual psychology, as opening up the field to what he called "political psychology." 72 After observing in a 1920 survey of the Progressive era's political debates that, "of the three powers of government, the executive was the greatest gainer in public esteem," he became interested in the question of leadership. ${ }^{73}$ Rather than juxtaposing civic incompetence and rational leadership, he advanced an enlightening methodological insight according to which "the attractiveness of the leader and the attraction of the follower are the same phenomena, viewed from different sides." ${ }^{74}$ Notable scholars responded to his call for "studies of the qualities of political leadership." They included political historian, presidential advisor, and later member of Roosevelt's brain trust William Yandell Elliott of Harvard, who looked at European examples for modern leadership and found Mussolini to be the "prophet of the pragmatic era in politics." 75

The end of the purely political approach to the study of public opinion took several directions. Armed with new scientific ambitions, some scholars began focusing on voting behavior and explored an alliance with psychological methods for the "measurement of public opinion." ${ }^{76}$ The intersection of propaganda analysis and scientific method saw its most transformative impact in the 1930 and 
1940s work of communication theorist Harold D. Lasswell. ${ }^{77}$ On the other hand, outside the domain of political discourse, the ongoing reflections over the use of war propaganda prompted the emergence of cross-disciplinary interests in social behavioral techniques. Once the assumption of rational human conduct was bracketed off, a whole host of disciplines, including anthropology, sociology, and psychology, began to investigate the rational and irrational aspects of human behavior. Most remarkable, however, was the work conducted outside academic walls among the communication professionals in the emerging domain of the consumer economy.

\section{DEMOCRACY AND CONSUMER CULTURE}

Unlike concerned political observers and theorists, a whole class of professional journalists, press agents, and publicity experts argued that Germans' coarse approach to propaganda was giving the term a bad name. In their view, propaganda was "an essentially harmless refinement on the traditional American marketplace of ideas." ${ }^{78}$ As Jackson Lears has noted, for them "advertising the war effort was an exercise in democratic social engineering, not Prussian regimentation." 79 The postwar years were momentous: advertising saw an unprecedented explosion of relevance and visibility in American business and social life. Publicists and advertisers began to see themselves as part of the same legitimate and effectual profession. By the 1920 s the idea of audience manipulability had well-established academic, political, and professional currency. At the annual meetings of the professional advertising association, it was quite common "for heads of prestigious universities and national leaders [...] to enthusiastically hail advertising as 'an agent of civilization,' and 'the producer of desires which ends in creating demands." 80 What was in certain circles a doctrine of influence, in others could be "professionalized into the psychology of suggestion, which cast the consumer as an easy mark for the informed marketing strategist." ${ }_{11}$

The emergence of publicity as a legitimate profession did not occur in a vacuum but sprang from multiple antecedents, including the often-overlapping practices of theatrical press agentry and commercial advertising. In broad terms, publicity embodied the Progressives' opposition to corporate "secrecy," which they condemned as detrimental to the public interest. ${ }^{82}$ Even before the creation of the CPI, early twentieth-century American corporations realized that the best way to fight the charges of the muckraking press was to use the press to disseminate positive publicity about themselves.

In theory, news making and plain advertising or publicity were separate endeavors at odds with each other. In 1906, however, the Bookman had accused publicity practitioners of manufacturing "tainted news," and in 1914 the New York Times had described the conflict in Europe as the "the first press agents" war." ${ }_{3}$ In the mid-1920s, accusations against publicity adopted a novel formula: public 
relations were not only akin to propaganda but were also described derogatively as "higher hokum" - a ploy, that is ${ }^{84}$ Yet, the press never came to condemn publicity or the PR profession for long or to distance itself from these practices. As Alan R. Raucher noted long ago, "the publicity's men's desire to have material printed and the editor's need for copy produced a marriage of convenience." ${ }^{5}$

The most outspoken and self-promoting representative of the rising public relations industry was a young Cornell graduate named Edward Bernays. He had served as press agent for Enrico Caruso and the Ballets Russes, worked for the CPI's Foreign Press Bureau, and attended the Paris Peace Conference as a member of the press team. His knowledge of the psychology of influence came from experience, readings, and a prominent family connection: he was Sigmund Freud's nephew twice over. ${ }^{86}$ Shrewd and ambitious, in 1919 he established his own business in New York, promoting himself as "public relations counsel," and acquired academic credentials by teaching courses on public relations at New York University in the early 1920s. He published one of the first books on public relations in 1923, Crystallizing Public Opinion, which he followed in 1928 with the even more ambitious volume Propaganda. ${ }^{87}$ While engaging critically with Lippmann's views about the dangerous manipulability of public opinion, Bernays did not often acknowledge his debts to the writings of the New Republic editor and at times turned him into an apologist for public relations. ${ }^{88}$

At the center of Bernays's understanding of the opportunities associated with publicity and public opinion management was his experience with the Creel Commission. In his recounting, it had "opened the eyes of the intelligent few in all departments of life to the possibilities of regimenting the public mind." ${ }_{9}$ In contrast to German wartime practices, "modern propaganda," Bernays wrote in 1927 , "is a consistent, enduring policy of creating or shaping events to influence the relations of the public to a given enterprise. Perhaps 'public relations' is a more accurate term than propaganda." 90 Whatever the name, he argued, "the conscious and intelligent manipulation of the organized habits and opinions of the masses is an important element in democratic societies." ${ }^{11}$ In a chapter in Crystallizing Public Opinion entitled "Propaganda and Political Leadership," he lamented that "the methods of our contemporary politicians, in dealing with the public, are as archaic and ineffective as the advertising methods of business in 1900 would be today." The great challenge of our modern democracy, he remarked, "is how to induce our leaders to lead [. . .] When Napoleon said, 'Circumstance? I make circumstance', he expressed very nearly the spirit of the public relations counsel's work." ${ }^{22}$ To Bernays, the affinities between the Corsican leader's brilliance and the emerging professional field were obvious. After all, he remarked, "good government can be sold to a community just as any other commodity. True, it is an intangible product [. . . ] but not more intangible than the creation of a desire for breakfast foods or a new style of hats or a new philosophic thought or theory." ${ }^{33}$ The modern principles and practices of "universal 
education" for the common man have only expanded the possibilities of manipulation, not reduced them. "Instead of a mind, universal literacy has given him a rubber stamp [. . . ] inked with advertising slogans [. . .] but quite innocent of original thought" because of propaganda's "organized effort to spread a particular belief or opinion." 94

Due to his success and his reputation, it is not surprising that Bernays worked also for Hollywood, albeit briefly. Possibly recognizing how his talent best fit the task of promoting studio stars, William Fox assigned him in 1917 "the special handling of Theda Bara in Cleopatra." He devised catchy slogans and sought to appeal to respectable spectators by stressing the film's educational value (i.e., Egyptomania, Roman history, art history). But his plans clashed with an industry culture that in the case of Bara preferred "an easy stimulation of the senses and their imagination by powerful mass effects [and] by voluptuousness." ${ }^{95}$ In publications and personal documents, he denounced Hollywood's sensationalist schemes as part of "a crude, crass, manufacturing business." ${ }^{96}$ In a career that spanned decades, he rarely worked again for the film industry, preferring instead to collaborate with Cosmopolitan magazine, the publisher Bernarr MacFadden, and several large corporations.

Still, Bernays succeeded in his goal of redeeming the business of publicity from associations with Barnum-like trickstering to a semirespectable profession, one that he helped popularize as public relations. While his critics viewed his tactics as evidence of opportunism and deception, Bernays sought to invest his role with a serious intellectual status and an allegedly responsible social goal-as an opportunity to expand the knowledge of a busy public. He had learned valuable lessons about the critical role of established opinion leaders from the prince of publicity men, Ivy Lee. He had applied them as early as 1913, when he managed to have medical and religious authorities endorse a controversial stage play on syphilis, which eventually led to a widely publicized performance at Wilson's White House. What he ultimately perfected was the codification of strategies for the creation of newsworthy events and their widespread popularization through the use of experts or celebrities who provided "leader approval." In his view, even presidents could benefit from endorsement. In 1924 he organized a promotional event for President Coolidge's election bid. Asked to reverse the widespread opinion that Coolidge was "weaned on a pickle," Bernays thought of co-opting Broadway dancers and actors, including Al Jolson, for an official breakfast at the White House. ${ }^{97}$ The pseudo-event aimed to produce stories and photographs of the president in the company of individuals who "symbolized warmth, extroversion and Bohemian camaraderie." At the event Jolson sang "Keep Coolidge." The headline on the New York Times front page read "Actors Eat Cakes with the Coolidges: President Nearly Laughs." ${ }^{88}$ Bernays used these testimonials as part of a much-emulated strategy of publicity stunts, which he called "over acts," which secured free news coverage. 
If advertising was an explicit plan to convey information to sell products or services, what Bernays practiced and later theorized was something that a 1926 study identified as "news publicity" - an oblique and much more effective way to market an idea, a product, or an individual. ${ }^{99}$ "The intrinsic nature of news publicity material is news [...] News publicity is information, not argument," its authors asserted. "It educates, but does not sell. [It] is not directly concerned with merchandising, despite the fact that there is an occasional element of news in what is for sale." ${ }^{100}$ Publicity, in other words, constituted a most effective form of information strategy when it masqueraded as news.

Bernays's celebration of "special pleaders" pervaded the 1920s. Notwithstanding Lippmann's eloquent and legitimate concerns for their impact on democracy, the practices that Bernays adopted, reworked, and endorsed became the modus operandi of film and political promotion and played no small role in shaping and enhancing the fame of Valentino and Mussolini. In a decade often derogatorily known as the age of ballyhoo, the industry could count on several Bernays-like figures who, albeit largely unknown and operating in the background, had no moral qualms about stunts and pseudo-events. In a two-part article, entitled "The Business of Motion Pictures" and published in 1927 in the Saturday Evening Post, Carl Laemmle commented on the role of "press agents' stunts" and the bad reputation that "exploitation" had attracted in the press and elsewhere. Defending the actions of "ballyhoo men" against moralistic detractors, Laemmle argued that "no matter what are the various views and definitions, exploitation, as I take it, is merely advertising the picture to the public in an unusual and convincing manner." ${ }^{101}$ It was actually more than that.

To assess how Bernays's exemplary work contributed to the changes affecting film and press cultures, one has to go back to the Supreme Court's Mutual Film Corporation decision discussed in chapter 1 . The stark distinction between the motion picture business, which for the court had no value as public interest, and the press was doubly contradicted by the facts. Griffith's radical and influential approach to motion pictures from 1915 on, together with the CPI's co-optation of Hollywood in 1917-1918, revealed that cinema was both a business and an organ of public opinion very much like the press-not one at the expense of the other. The press itself, in fact, was more than a mere conveyer of information and public opinion. It was also a private business and a fast-expanding one. Mainstream observers of the press's changes and workings were quite vocal about the illusion of any neat distinction between journalistic ideals and commercial realities.

In the late 1920s, journalist and author Silas Bent gave an enlightening public talk on the disturbing changes that had recently informed American journalism. Entitled "A Menace to Democracy: The Press in America-Is It Free?" and published in a 1929 volume, Bent's talk began by detailing the striking technological changes, from the introduction of economical pulpwood papers and photographic reproduction to transatlantic cables, that had turned a 
limited commercial enterprise into a mass industry with inevitable links to powerful commercial and financial interests. ${ }^{102}$ The profitable partnership with advertising had dramatically lowered the cost of newspapers, inflamed harsh competition, and tilted news coverage toward sensationalism. While pro-reform editorialists may have launched crusades against profiteering, the same papers' news columns did not. Bent denounced the fact that the press was experiencing "grave encroachments on freedom of opinion and of speech" from both the business and political worlds. ${ }^{103}$ While revealing the financial dimension of the journalistic profession, he noted that the massive revenue increase derived from years' worth of advertising made it "preposterous" to suppose that the news business could ignore its best customers. At work, in his view, was not just news distortion but a more sinister change in news making and news consumption that turned the reader from recipient of objective reporting into a "ready victim of the advertiser's exploitation." ${ }^{104}$

For Bent, the two key strategies were the deployment of "stereotypes," or "stories which appealed to primary passions and unconscious hungers," and the use of celebrities, evident in the press's penchant "to ballyhoo night club hostesses, bathing beauties, pugilists, baseball players, channel swimmers, stunt aviators and tennis stars, solely for the aggrandizement of its own pocketbook." ${ }^{105}$ With a polemic tone suggestive of Lippmann, he concluded that in America "the manufacture of public opinion [.. .] is in the hands of private enterprise which thinks only of its own treasury and very seldom of the public good." ${ }^{106}$

The idealized distinction between private business and public good, between private and public profit, had been the basis of Progressive politicians' rhetoric. But the outcome of their actions, by an ironic heterogony of ends, intertwined private and public domains in creative new ways. In his dated but still useful study of business and public relations in early twentieth-century America, Alan Raucher questioned the conventional wisdom that opposed Progressivism to unfettered business. On the surface, Theodore Roosevelt and muckraking journalism had punctured the sacred inviolability of American business giants. In truth, however, Progressivism had provided a "rationalization of business through government regulation" which, in conjunction with the development of new methods of communication, had reformulated the role of American business in the country's polity. ${ }^{107}$ American businesses may have acted in self-defense against Progressivist attacks. But in a move that appropriated a Progressive argument, they also developed a new public morality-or corporate social responsibility, as we might say today. In contrast to William Henry Vanderbilt's "the public be damned," uttered in 1882 in response to a reporter's question about railway routes and fares, the development of the public relations profession responded to modern corporations' new public-centered stance. It signaled the rejection of a model of unrestricted competition and laissez-faire in favor of one ostensibly based on the widest possible benefit and thus constantly engaged in the use of mass communication. 
In this light, the heritage of Progressivism lasted beyond its usual chronological boundaries. By 1917, in fact, corporations that had faced public hostility and the threat of regulations were using publicity agents not just to counter attacks but also to publicize proto-welfare programs and new safety measures, as well as to promote management's close relationship with civic leaders. ${ }^{108}$ News publicity was the preferred medium to "make a private cause look like a public cause and [... . to create of a public cause a public duty" ${ }^{109}$ Some, like journalist and editor Harper Leech went beyond the straightforward assertion that public relations activities were the legitimate function of business and argued that they were none other than the guarantors of the right to free speech. In a 1927 polemical contribution, "Is American Business Entitled to the Rights of Free Speech?," Leech made a vehement case in the affirmative. In his presidentially appointed role as public relations director of the Railroad Labor Board, Leech stressed that American civilization had conferred "upon the masses benefits never before possible to them" and denied that business's "scientific civilization" had any "conscious social policy." Against the development and obvious benefits of capitalist enterprise, he denounced as "intellectual perversity" the positions of "radical college professors, kept liberals, [and] pink journals of opinion" who denied businesses "the right of free speech." Theirs was an "anti-capitalist" stance that, Leech happily noted, did not pervade mainstream media, which was becoming "a vast industry itself."110

We have come full circle. In 1915 cinema was regarded by the Supreme Court as simply a business and thus not as "organ of opinion" entitled to free speech. By 1927 , it was not simply that the motion picture industry qua national industry was recognized as an organ of opinion but also that large corporations, and particularly public utility companies, had to operate as both businesses and organs of opinion. The Great War had played a role. Before 1917, public utility businesses had established a few practices that grew to national and international scale during the European conflict. As Raucher concedes, the Creel Committee introduced a "scope of its operations" on the national and international level that in 1917-1918 was unprecedented, and the government's involvement uniquely helped the publicity business gain the legitimacy of a professional vocation. ${ }^{111}$ During the war years, the public status of American business was changing: private profit and public good were not in opposition any more, as the Progressive rhetoric had always intimated, but were running on seemingly parallel tracks. In the arena of public opinion, the regimentation of an old profession, variously renamed publicity agent, public relations counsel, and so on, discernably intertwined business and public interest.

Cinema did not remain impervious to these dynamics. During and immediately after the war, through a massive use of public relations activities pervading the press and public spaces, cinema emerged as America's most influential mass entertainment and, as such, a public utility of sort. At its center was a key public relations device, the authority of celebrities. As special pleaders, celebrities were 
deployed to manage the rise of American film spectators' attendance in lavish new movie theaters and to broadcast modes of behavior centered on the values of individualism, leadership, and success. The next chapter will show how the motion picture industry, just as it was acquiring the financial and managerial fundamentals of more established corporate entities, gained unprecedented commercial and cultural hegemony as an American industry both domestically and in the world. Eventually, as we shall see in parts 2 and 3, in synch with its ambitions for transnational appeal, Hollywood's celebrity culture found itself inevitably crowded with foreign figures and infused with international cultural models. 